\title{
A Mouse Model of Fluorescent Protein-expressing Disseminated Peritoneal Lymphoma for Fluorescence-guided Surgery
}

\author{
TAKURO MATSUMOTO ${ }^{1}$, ATSUSHI SUETSUGU ${ }^{1,2,3}$, KOSUKE HASEGAWA $^{1}$, \\ MIKI NAKAMURA ${ }^{1}$, YUHEI SHIBATA ${ }^{1}$, HITOMI AOKI ${ }^{1}$, TAKAHIRO KUNISADA $^{1}$, \\ HISASHI TSURUMI ${ }^{1}$, MASAHITO SHIMIZU ${ }^{1}$, MICHAEL BOUVET ${ }^{3}$ and ROBERT M. HOFFMAN ${ }^{2,3}$ \\ ${ }^{1}$ Gifu University Graduate School of Medicine, Gifu, Japan; \\ ${ }^{2}$ AntiCancer, Inc., San Diego, CA, U.S.A.; \\ ${ }^{3}$ Department of Surgery, University of California San Diego, San Diego, CA, U.S.A.
}

\begin{abstract}
Background: Fluorescence-guided surgery (FGS) of tumors is an area of intense development. Peritoneallydisseminated cancer, however, represents a difficult surgical challenge. Materials and Methods: To help meet this challenge, EL4 mouse T-cell lymphoma cells expressing red fluorescent protein (RFP) were injected intraperitoneally in nude mice. Results: Two weeks after injection of EL4-RFP cells, established peritoneally-disseminated tumors were observed. FGS was performed using a hand-held portable fluorescence imaging system (Dino-Lite). FGS enabled detection of very small peritoneal disseminated tumors and completely resected them in contrast to bright-light which only partially detected the tumors. Conclusion: The present report indicates the feasibility of FGS of peritoneally-disseminated cancer.
\end{abstract}

Our laboratory has developed fluorescence-guided surgery (FGS) in mouse models of cancer (1). FGS on orthotopic nude-mouse models of colon cancer (2-6), pancreatic cancer (7-19), lung cancer (20), sarcoma (21), glioma (22) and liver metastasis $(5,6,23)$ has been shown to have significant improvement over bright-light surgery (BLS). A small handheld fluorescence imaging device has recently been used for FGS in orthotopic mouse models $(4,13)$ that can be used in the clinic. The mouse models used thus far for FGS have

This article is freely accessible online.

Correspondence to: Robert M. Hoffman, Ph.D., AntiCancer, Inc., 7917 Ostrow Street, San Diego, CA 92111, U.S.A. Tel: +1 8586542555, Fax: +1 8582684175, e-mail: all@anticancer.com or Atsushi Suetsugu MD, Ph.D., Department of Gastroenterology, Gifu University Graduate School of Medicine, Gifu, Japan, 1-1 Yanagido, Gifu 501-1194, Japan. Tel: +81 582306308, Fax: +81 582306310,e-mail: asue@gifu-u.ac.jp

Key Words: RFP, nude mice, malignant lymphoma, fluorescence guided surgery, imaging, peritoneal dissemination. also included patient-derived orthotopic xenograft (PDOX) models $(3,4,13,15,16,18,19)$ in nude mice.

Recently, we have developed a model of the EL-4 mouse lymphoma expressing red fluorescent protein (EL4-RFP). A syngeneic color-coded imageable lymphoma model was previously established to visualize recruitment of host stromal cells by malignant lymphoma during metastasis. EL4-RFP cells were injected into the tail vein of C57/BL6GFP transgenic mice. EL4-RFP metastasis was observed in multiple sites, which were also enriched in host GFPexpressing cells. Furthermore, EL4-RFP lymphoma cells were also observed along with host GFP stromal cells in the peripheral blood and bone marrow, as well as the liver (24).

RFP-expressing EL4 lymphoma cells were also previously injected subcutaneously in C57/BL6 GFP transgenic mice and formed tumors by 35 days after cell transplantation. Using the Dino-Lite hand-held, portable fluorescence imaging system, subcutaneous tumors including the tumor microenvironment (TME) were clearly visualized and resected. In the resected tumor, GFP-expressing host stromal cells, including adipocyte-like cells, and blood vessels containing lymphocytes were observed by color-coded confocal microscopy to be closely associated with the lymphoma cells (25).

The present report describes successful FGS of peritoneally-disseminated EL-4-RFP, a model of highlychallenging cancer surgery.

\section{Materials and Methods}

Mouse experiments. All experiments were conducted in accordance with the institutional guidelines of Gifu University, Gifu, Japan, and approved by the animal research committee and the committee on living modified organisms of Gifu University. In order to minimize any suffering of the animals, anesthesia and analgesics were used for all surgical experiments. Animals were anesthetized by intramuscular injection of a $0.02 \mathrm{ml}$ solution of $100 \mathrm{mg} / \mathrm{kg}$ ketamine. The response of animals during surgery was monitored to ensure adequate depth of anesthesia. The use of 


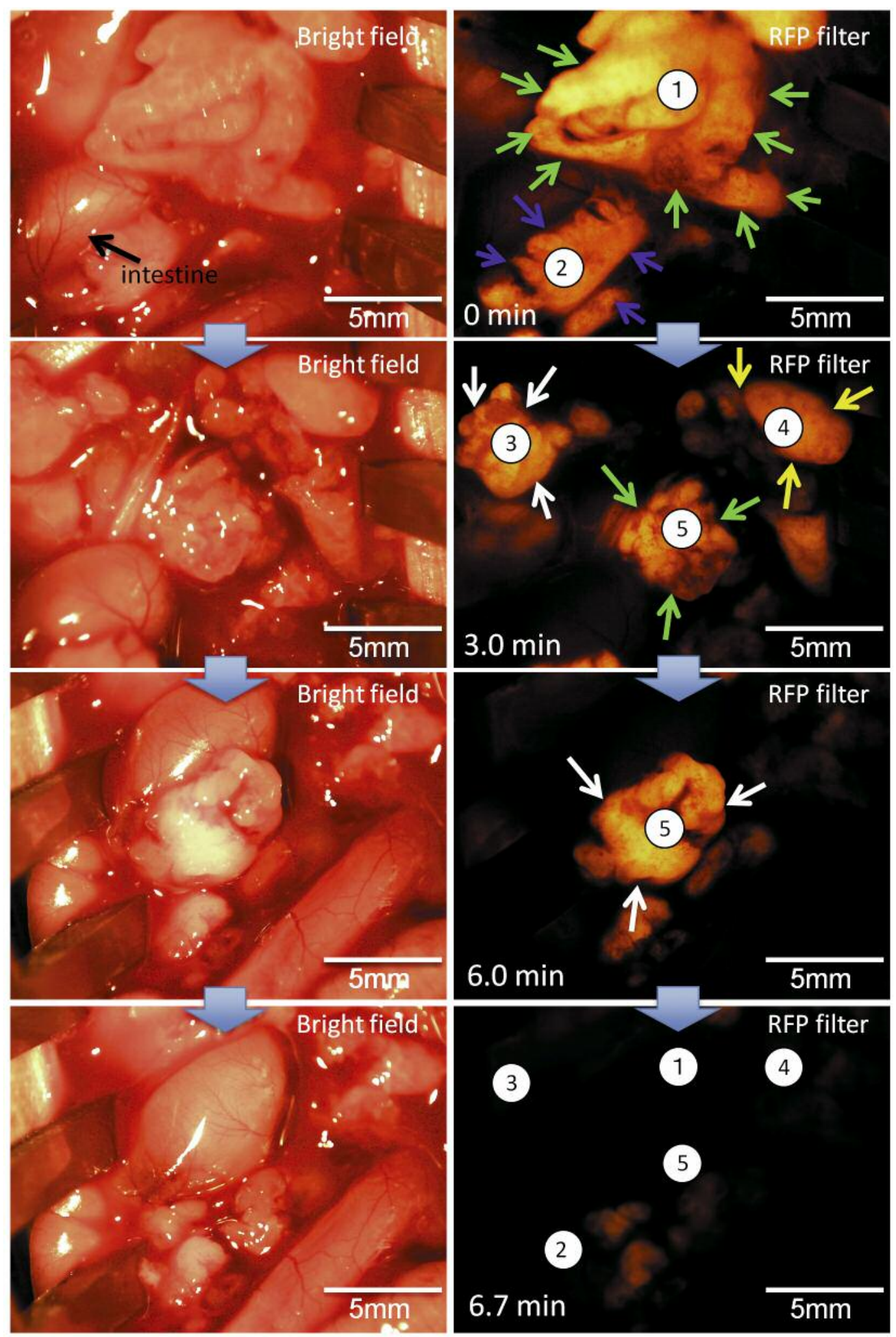

Figure 1. Time course of fluorescence-guided surgery (FGS) of peritoneal-disseminated lymphoma. Pre-operative and time-course intra-operative images are shown. Left panels show bright-field images and right panels are fluorescence images of peritoneally-disseminated tumors obtained with the Dino-Lite hand-held fluorescence scope (bar $=5 \mathrm{~mm})$. Under bright light, tumors were very difficult to distinguish. In contrast, under fluorescence, tumors were clearly visualized as indicated (arrows). As FGS proceeded, tumors were removed according to their number from 1 to 5. 

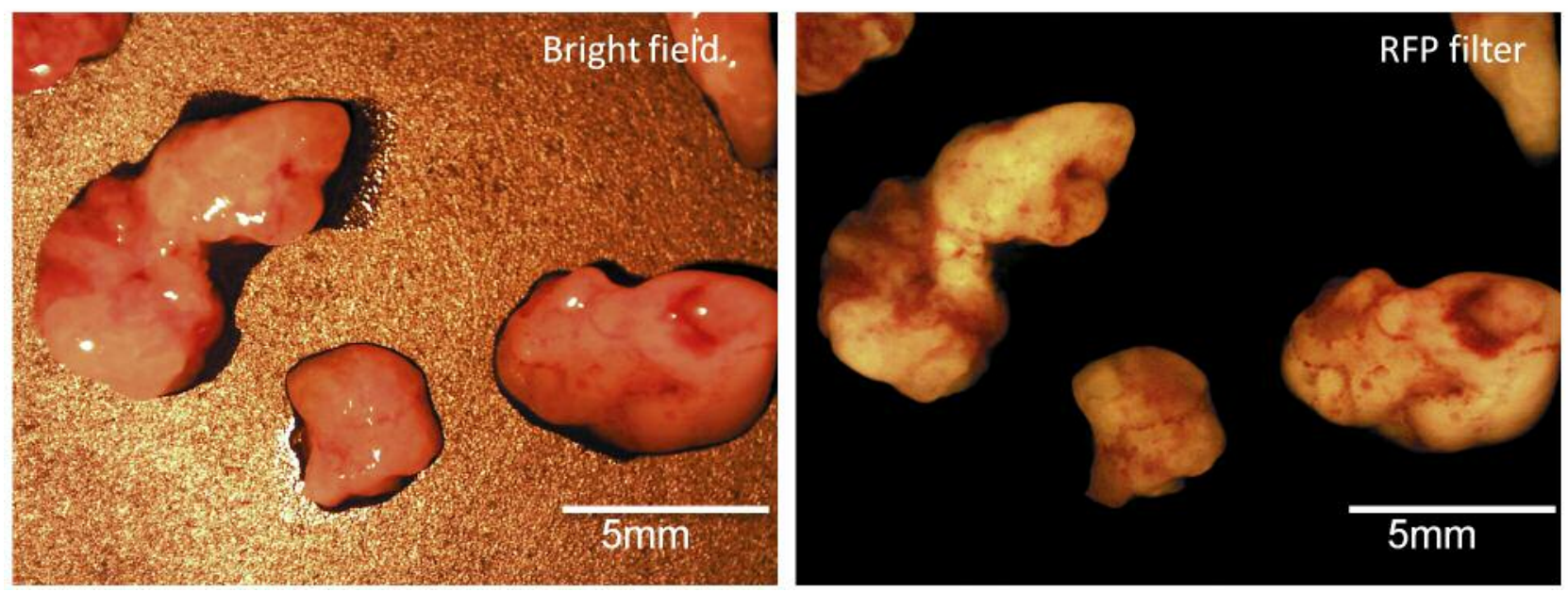

Figure 2. Resected specimens. Left panel shows bright-field images and right panel shows red fluorescent protein (RFP) images of FGS resected peritoneally-disseminated tumors (bar $=5.0 \mathrm{~mm})$.
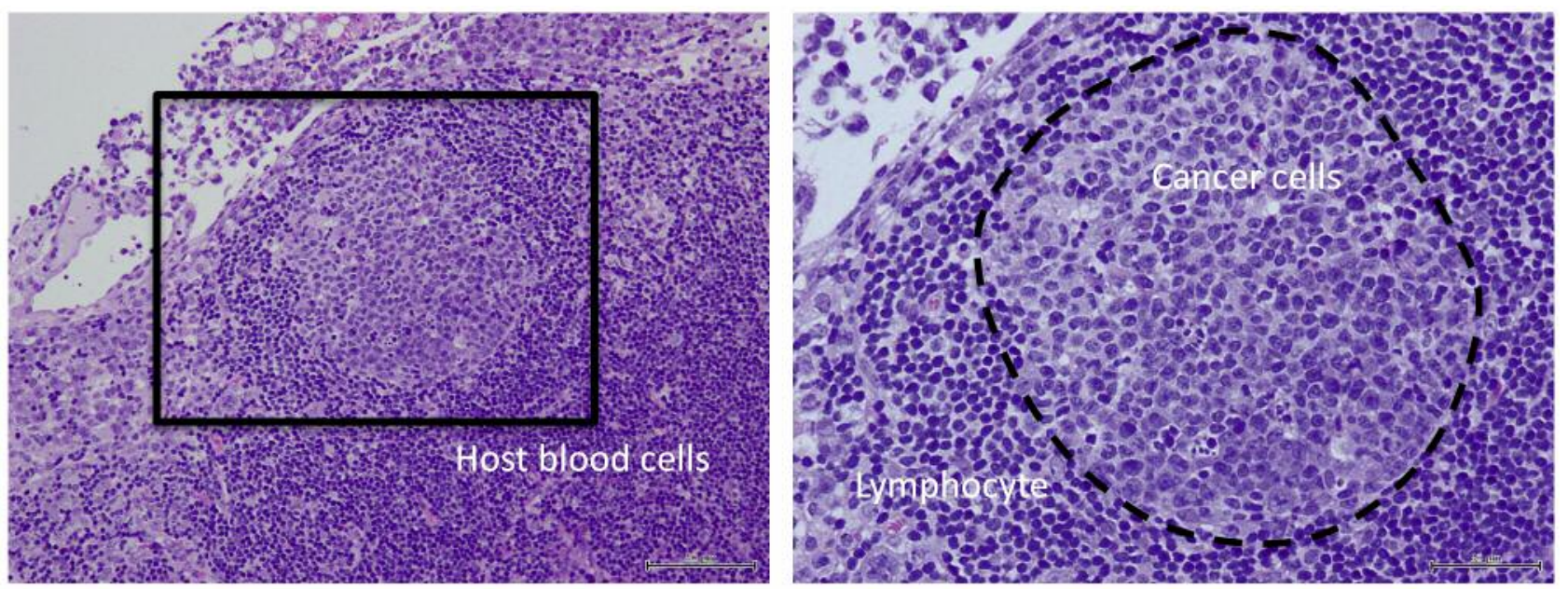

Figure 3. Hematoxylin-eosin staining of FGS resected specimens. Left panel shows low-magnification image (bar=100 $\mu \mathrm{m})$ and right panels shows high-magnification image (bar=100 $\mu \mathrm{m}$ ). Cancer tissue (marked by dotted line) is surrounded by normal lymphocytes.

animals was necessary to develop FGS of peritoneal metastasis Animals were housed with no more than 5 per cage, in a barrier facility on a high efficiency particulate arrestance (HEPA)-filtered rack under standard conditions of 12-hour light/dark cycles. Seven-week-old BALB/c-nu/nu nude mice (Charles River Laboratories, Inc., Yokohama, Japan) were used in this study. Mice were kept in a barrier facility under HEPA filtration (as noted above). Mice were fed with an autoclaved laboratory rodent diet. All mouse surgical procedures and imaging were performed with the animals anesthetized by subcutaneous injection of the ketamine mixture described above.

Cell line and culture condition. EL-4, a mouse lymphoma cell line, was established from a lymphoma induced in a C57BL mouse by 9,10-dimethyl-1,2-benzanthracene (DMBA). The cells were maintained in RPMI 1640 medium supplemented with $10 \%$ heatinactivated fetal bovine serum (FBS), $1 \%$ penicillin and streptomycin (Gibco-BRL, Grand Island, NY, USA). The cells were cultured at $37^{\circ} \mathrm{C}$ in a $5 \% \mathrm{CO}_{2}$ incubator (25).

Red fluorescent protein (RFP) transduction of lymphoma cells. EL4 lymphoma cells were labeled with RFP as previously reported (24) using retroviruses expressing RFP. EL-4 cells were transfected with retroviruses.

EL4-RFP peritoneally-disseminated lymphoma model. Seven-weekold BALB/c-nu/nu nude mice were used as the host for EL4-RFP lymphoma cells. EL4-RFP lymphoma cells were first harvested and washed three times with cold serum-free medium and then resuspended with serum-free RPMI 1640 medium. RFP EL4 
lymphoma cells $\left(1 \times 10^{6}\right.$ in $100 \mu \mathrm{l}$ serum-free medium $)$ were injected intraperitoneally in nu/nu (nude) mice. Two weeks after injection, peritoneal metastasis was confirmed by laparotomy.

FGS of peritoneally-disseminated lymphoma. Two weeks after intraperitoneal administration of EL4-RFP, peritoneally-disseminated lymphoma was observed. FGS was performed using the Dino-Lite imaging system (AM4113TYFGW Dino-Lite Premier; AnMo Electronics Corporation, Hsinchu, Taiwan) $(4,13)$.

\section{Results and Discussion}

FGS resection of peritoneally-disseminated lymphoma. We performed FGS of peritoneally-disseminated lymphoma demonstrated by pre-operative and time-course intra-operative imaging (Figure 1). The resection of each peritoneallydisseminated tumor was recorded in real time with the DinoLite (Figure 1). The tumors were removed with minimal organ injury and with maximal resection margins.

Resected tumors are shown in bright-field and under fluorescence (Figure 2). Tumor margins are sharply visualized with the Dino-Lite with very little autofluorescence signal. Under bright light, tumor margins were unclear (Figures 1,2).

Histopathological evaluation of margins of the resected tumors are shown in Figure 3. Tumors removed by FGS contained abundant cancer-associated stromal cells, surrounded by normal tissues. Viable cancer cells were not detected in the resected margins. This result shows the precision of FGS with the portable hand-held Dino-Lite on even very small tumor nodules containing abundant host stromal cells. This technique allowed maximal tumor resection with minimal or no residual lymphoma.

Tumors are often obscure in the normal background, difficult to distinguish and overlooked during surgery. Cancer cells labeled with fluorescence can be accurately detected and entirely removed during surgery. Even peritoneally-disseminated cancer, a particularly difficult surgical challenge, can be successfully resected by FGS, as demonstrated in the present report.

\section{Conclusion}

FGS has been shown to detect tiny peritoneally-disseminated lymphoma and completely resect them. The results of the present study suggest that FGS has clinical potential for peritoneally-disseminated cancer. The pioneering studies of our laboratories have demonstrated two strategies for labeling tumors for FGS: a telomerase-dependent adenovirus containing GFP (26) and a fluorescent conjugated tumor-specific antibody (27). FGS in now emerging in the clinic (28-30) and should become the standard paradigm in the near future.

\section{Conflicts of Interest}

None of the Authors have any conflict of interest with regard to this study.

\section{Dedication}

This paper is dedicated to the memory of A.R. Moossa, MD and Sun Lee, MD.

\section{References}

1 Bouvet $\mathrm{M}$ and Hoffman RM: Glowing tumors make for better detection and resection. Sci Transl Med 3: 110fs 10, 2011.

2 Metildi CA, Kaushal S, Snyder CS, Hoffman RM and Bouvet M: Fluorescence-guided surgery of human colon cancer increases complete resection resulting in cures in an orthotopic nude mouse model. J Surg Res 179: 87-93, 2013.

3 Metildi C,A, Kaushal S, Luiken GA, Talamini MA, Hoffman $\mathrm{RM}$ and Bouvet M: Fluorescently-labeled chimeric anti-CEA antibody improves detection and resection of human colon cancer in a patient-derived orthotopic xenograft (PDOX) nude mouse model. J Surg Oncol 109: 451-458, 2014.

4 Hiroshima Y, Maawy A, Metildi CA, Zhang Y, Uehara F, Miwa S, Yano S, Sato S, Murakami T, Momiyama M, Chishima T, Tanaka K, Bouvet M, Endo I and Hoffman RM: Successful fluorescence-guided surgery on human colon cancer patientderived orthotopic xenograft mouse models using a fluorophoreconjugated anti-CEA antibody and a portable imaging system. J Laparoendosc Adv Surg Tech A 24: 241-247, 2014.

5 Maawy A, Hiroshima Y, Zhang Y, Luiken GA, Hoffman RM and Bouvet M: Polyethylene glycol (PEG) linked to near infrared (NIR) dyes conjugated to chimeric anti-carcinoembryonic antigen (CEA) antibody enhances imaging of liver metastases in a nudemouse model of human colon cancer. PLoS One 9: e97965, 2014.

6 Yano S, Takehara K, Miwa S, Kishimoto H, Hiroshima Y, Murakami T, Urata Y, Kagawa S, Bouvet M, Fujiwara T and Hoffman RM: Improved resection and outcome of colon-cancer liver metastasis with fluorescence-guided surgery using in situ GFP labeling with a telomerase-dependent adenovirus in an orthotopic mouse model. PLoS One 11: e0148760, 2016.

7 McElroy M, Kaushal S, Luiken G, Moossa AR, Hoffman RM and Bouvet $\mathrm{M}$ : Imaging of primary and metastatic pancreatic cancer using a fluorophore-conjugated anti-CA19-9 antibody for surgical navigation. World J Surgery 32: 1057-1066, 2008.

8 Tran Cao H, Kaushal S, Lee C, Snyder CS, Thompson KJ, Horgan S, Talamini MA, Hoffman RM and Bouvet M: Fluorescence laparoscopy imaging of pancreatic tumor progression in an orthotopic mouse model. Surg Endo 25: 48-54, 2011.

9 Tran Cao HS, Kaushal S, Menen RS, Metildi CA, Lee C, Snyder CS, Talamini MA, Hoffman RM and Bouvet M: Submillimeter-resolution fluorescence laparoscopy of pancreatic cancer in a carcinomatosis mouse model visualizes metastases not seen with standard laparoscopy. J Laparoendosc Adv Surg Tech A 21: 485-489, 2011.

10 Metildi CA, Kaushal S, Lee C, Hardamon CR, Snyder CS, Luiken GA, Talamini MA, Hoffman RM and Bouvet M: An LED light source and novel fluorophore combinations improve fluorescence laparoscopic detection of metastatic pancreatic cancer in orthotopic mouse models. J Am Coll Surg 214: 997-1007, 2012.

11 Tran Cao HS, Kaushal S, Metildi CA, Menen RS, Lee C, Snyder CS, Messer K, Pu M, Luiken GA, Talamini MA, Hoffman RM and Bouvet M: Tumor-specific fluorescence antibody imaging enables accurate staging laparoscopy in an orthotopic model of pancreatic cancer. Hepatogastroenterology 59: 1994-1999, 2012. 
12 Maawy AA, Hiroshima Y, Kaushal S, Luiken G,A, Hoffman RM and Bouvet M: Comparison of a chimeric anti-carcinoembryonic antigen antibody conjugated with visible or near-infrared fluorescent dyes for imaging pancreatic cancer in orthotopic nude mouse models. J Biomed Optics 18: 126016, 2013.

13 Hiroshima Y, Maawy A, Sato S, Murakami T, Uehara F, Miwa S, Yano S, Momiyama M, Chishima T, Tanaka K, Bouvet M, Endo I and Hoffman RM: Hand-held high-resolution fluorescence imaging system for fluorescence-guided surgery of patient and cell-line pancreatic tumors growing orthotopically in nude mice. J Surg Res 187: 510-517, 2014.

14 Hiroshima Y, Maawy A, Zhang Y, Sato S, Murakami T, Yamamoto M, Uehara F, Miwa S, Yano S, Momiyama M, Chishima T, Tanaka K, Bouvet M, Endo I and Hoffman RM: Fluorescence-guided surgery in combination with UVC irradiation cures metastatic human pancreatic cancer in orthotopic mouse models. PLoS One 9: e99977, 2014.

15 Hiroshima Y, Maawy A, Zhang Y, Murakami T, Momiyama M, Mori R, Matsuyama R, Katz MH, Fleming JB, Chishima T, Tanaka K, Ichikawa Y, Endo I, Hoffman RM and Bouvet M: Metastatic recurrence in a pancreatic cancer patient derived orthotopic xenograft (PDOX) nude mouse model is inhibited by neoadjuvant chemotherapy in combination with fluorescenceguided surgery with an anti-CA 19-9-conjugated fluorophore. PLoS One 9: e114310, 2014.

16 Hiroshima Y, Maawy A, Zhan Y, Murakami T, Momiyama M, Mori R, Matsuyama R, Chishima T, Tanaka K, Ichikawa Y, Endo I, Hoffman RM and Bouvet M: Fluorescence-guided surgery, but not bright-light surgery, prevents local recurrence in a pancreatic cancer patient-derived orthotopic xenograft (PDOX) model resistant to neoadjuvant chemotherapy (NAC). Pancreatology 15: 295-301, 2015.

17 Maawy AA, Hiroshima Y, Zhang Y, Garcia-Guzman M, Luiken GA, Kobayashi H, Hoffman RM and Bouvet M: Photoimmunotherapy lowers recurrence after pancreatic cancer surgery. J Surg Res 197: 5-11, 2015.

18 Yano S, Hiroshima Y, Maawy A, Kishimoto H, Suetsugu A, Miwa S, Toneri M, Yamamoto M, Katz MHG, Fleming JB, Urata Y, Tazawa H, Kagawa S, Bouvet M, Fujiwara T and Hoffman RM: Color-coding cancer and stromal cells with genetic reporters in a patient-derived orthotopic xenograft (PDOX) model of pancreatic cancer enhances fluorescenceguided surgery. Cancer Gene Ther 22: 344-350, 2015.

19 Hiroshima Y, Maawy A, Zhang Y, Garcia-Guzman M, Heim R, Makings L, Liuken G, Kobayashi H, Tanaka K, Endo I, Hoffman RM and Bouvet M: Photoimmunotherapy inhibits tumor recurrence after surgical resection on a pancreatic cancer patientderived orthotopic xenograft (PDOX) nude mouse model. Ann Surg Oncol 22: S1469-1474, 2015.

20 Yano S, Zhang Y, Miwa S, Kishimoto H, Urata Y, Bouvet M, Kagawa S, Fujiwara T, and Hoffman RM: Precise navigation surgery of tumours in the lung in mouse models enabled by in situ fluorescence labelling with a killer-reporter adenovirus. BMJ Open Respiratory Research 2: e000096, 2015.

21 Yano S, Miwa S, Kishimoto H, Uehara F, Tazawa H, Toneri M, Hiroshima Y, Yamamoto M, Urata Y, Kagawa S, Bouvet M, Funiwara $\mathrm{T}$ and Hoffman RM: Targeting tumors with a killerreporter adenovirus for curative fluorescence-guided surgery of soft-tissue sarcoma. Oncotarget 6: 13133-13148, 2015.
22 Yano S, Miwa S, Kishimoto H, Toneri M, Hiroshima Y, Yamamoto M, Bouvet M, Urata Y, Tazawa H, Kagawa S, Funiwara $\mathrm{T}$ and Hoffman RM: Experimental curative fluorescence-guided surgery of highly invasive glioblastoma multiforme selectively labeled with a killer-reporter adenovirus. Mol Ther 23: 1182-1188, 2015.

23 Murakami T, Hiroshima Y, Zhang Y, Bouvet M, Chishima T, Tanaka K, Endo I and Hoffman RM: Improved disease-free survival and overall survival after fluorescence-guided surgery of liver metastasis in an orthotopic nude mouse model. J Surg Oncol 112: 119-124, 2015.

24 Matsumoto T, Suetsugu A, Shibata Y, Nakamura N, Aoki H, Kunisada T, Tsurumi H, Shimizu M and Hoffman RM: A colorcoded imageable syngeneic mouse model of stromal-cell recruitment by metastatic lymphoma. Anticancer Res 35: 4647$4654,2015$.

25 Hasegawa K, Suetsugu A, Nakamura M, Matsumoto T, Kunisada T, Shimizu M, Saji S, Moriwaki H, Bouvet M and Hoffman RM: Color-coded imaging enables fluorescence-guided surgery to resect the tumor along with the tumor microenvironment in a syngeneic mouse model of EL-4 lymphoma. Anticancer Res, in press.

26 Kishimoto H, Zhao M, Hayashi K, Urata Y, Tanaka N, Fujiwara $\mathrm{T}$, Penman $\mathrm{S}$ and Hoffman RM: In vivo internal tumor illumination by telomerase-dependent adenoviral GFP for precise surgical navigation. Proc Natl Acad Sci USA 106: 14514-14517, 2009.

27 Kaushal S, McElroy MK, Luiken GA, Talamini MA, Moossa AR, Hoffman RM and Bouvet M: Fluorophore-conjugated antiCEA antibody for the intraoperative imaging of pancreatic and colorectal cancer. J Gastrointest Surg 12: 1938-1950, 2008.

28 Urano Y, Sakabe M, Kosaka N, Ogawa M, Mitsunaga M, Asanuma D, Kamiya M, Young MR, Nagano T, Choyke PL and Kobayashi H: Rapid cancer detection by topically spraying a Yglutamyltranspeptidase-activated, fluorescent probe. Sci Transl Med 3: 110-119, 2011

29 van Dam GM, Themelis G, Crane LM, Harlaar NJ, Pleijhuis RG, Kelder W, Sarantopoulos A, de Jong JS, Arts HJ, van der Zee AG, Bart J, Low PS and Ntziachristos V: Intraoperative tumorspecific fluorescence imaging in ovarian cancer by folate receptor- $\alpha$ targeting: First in-human results. Nat Med 17: 13151319, 2011.

30 Stummer W, Pilchmeier U, Meinel T, Wiestler OD, Zanella F, Reulen HJ; ALA-Glioma Study Group: Fluorescence-guided surgery with 5-aminolevulinic acid for resection of malignant glioma: A randomised controlled multicentre phase III trial. Lancet Oncol 7: 392-401, 2006.
Received July 14, 2016

Revised July 26, 2016

Accepted August 2, 2016 